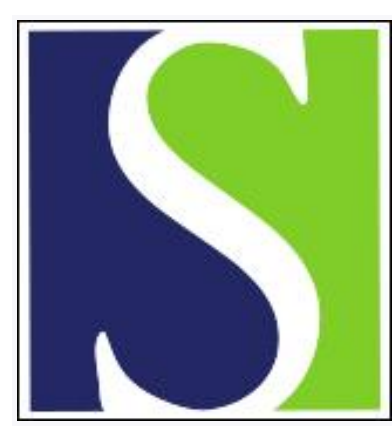

Scand J Work Environ Health 1996;22(1):58-61

https://doi.org/10.5271/sjweh.110

Issue date: Feb 1996

Clonal chromosome aberrations in myeloid leukemia after styrene exposure

by Kolstad HA, Pedersen B, Olsen J, Lynge E, Jensen G, Lisse I, Philip P, Tinggaard Pedersen $\mathrm{N}$

Key terms: case-referent study; epidemiology; neoplasm; occupational exposure; organic solvent

This article in PubMed: www.ncbi.nlm.nih.gov/pubmed/8685676

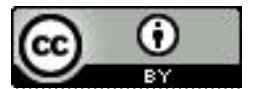




\title{
Clonal chromosome aberrations in myeloid leukemia after styrene exposure
}

\author{
by Henrik A Kolstad, MD, ${ }^{1,4}$ Bent Pedersen, MD, ${ }^{2}$ Jorn Olsen, MD, ${ }^{3}$ Elsebeth Lynge, PhD, ${ }^{4}$ Grethe Jensen, \\ MSc, ${ }^{5}$ Ida Lisse, MD, ${ }^{6}$ Preben Philip, MD, ${ }^{7}$ Niels Tinggaard Pedersen, $M D^{8}$
}

\begin{abstract}
Kolstad HA, Pedersen B, Olsen J, Lynge E, Jensen G, Lisse I, Philip P, Tinggaard Pedersen N. Clonal chromosome aberrations in myeloid leukemia after styrene exposure. Scand J Work Environ Health 1996;22:58-61.

Objectives The purpose of the study was to determine the risk of myeloid leukemia subclassified according to clonal chromosome aberrations in styrene-exposed workers.

Methods A nested case-referent study was carried out on 19 myeloid leukemia patients, of which 12 showed clonal chromosome aberrations, and 57 referents ascertained within the Danish reinforced plastics industry and similar industries with no styrene exposure.

Results A 2.5-fold increased risk for myeloid leukemia with clonal chromosome aberrations (95\% confidence interval $0.2-25.0$ ) was found among workers of companies with styrene exposure.

Conclusions The results suggest that styrene may cause leukemia through a clastogenic effect. But similar findings could also have been found if the exposure was associated with a specific subtype of leukemia prone to develop the chromosome aberrations in question. Due to the few observations and the lack of detailed exposure data, additional studies are needed to corroborate or refute the present suggestive findings.
\end{abstract}

Key terms case-referent study, epidemiology, neoplasms, occupational exposure, organic solvents.

Leukemia represents a heterogeneous group of diseases believed mainly to follow acquired genetic defects. Little is known about the environmental factors that induce these defects even though numerous analytic epidemiologic studies have been conducted (1). This situation may stem from a lack of awareness of the diversity of the leukemias not captured in current classification systems and the fact that different exposures may act through different causal pathways.

An association has been shown between the presence of clonal chromosome aberrations in hematopoietic tissue in acute myeloid leukemia and prior cytotoxic therapy or a history of occupational exposure to organic solvents $(2,3)$. These findings suggest that chromosome aberrations are, at least partly, linked with environmental factors and myeloid malignant growth.

Chromosome aberrations and DNA (deoxyribonucleic acid) adducts occur with increased frequency in leukocytes of styrene-exposed workers (4). In humans styrene is metabolized to styrene oxide, which is a potent mutagen and carcinogen in animals (4). Styreneexposed workers may have an increased risk of leuke$\operatorname{mia}(5,6)$.

Styrene is an organic solvent and an important component of plastics and synthetic rubber. A relatively small proportion of styrene is used in the production of containers and boats in reinforced plastics. In this industry the exposure level of styrene is high, and workers are not exposed to other known risk factors for leukemia (7). The industry is therefore recognized as an important setting for the study of the proposed association between styrene exposure and leukemia. Among workers employed in the Danish reinforced plastics industry during the 1960 s a moderately increased overall standardized incidence ratio for leukemia of 1.54 (30 cases, 95\% CI $1.04-2.19)$ was observed (8).

1 University of Aarhus, Institute of Epidemiology and Social Medicine, Århus, Denmark.

2 Danish Cancer Society, Department of Cytogenetics, Århus, Denmark.

3 The Danish Epidemiology Centre, Århus, Denmark.

4 Danish Cancer Society, Department of Cancer Epidemiology, Copenhagen, Denmark.

5 Frederiksberg Hospital, Department of Pathology, Copenhagen, Denmark.

6 Hvidovre Hospital, Department of Pathology, Copenhagen, Denmark.

7 Rigshospitalet, The Finsen Laboratory, Copenhagen, Denmark.

8 University Hospital of Odense, Department of Pathology, Odense, Denmark.

Reprint requests to: Dr Henrik A Kolstad, Department of Occupational Medicine, University Hospital of Aarhus, Nørrebrogade 44, DK-8000 Århus C, Denmark. 
The objective of this study was to determine whether the previously demonstrated association between styrene exposure and leukemia is mainly due to an association with myeloid leukemia subclassified according to clonal chromosome aberrations. The study addressed a possible mechanism in leukemogenesis associated with styrene exposure.

\section{Subjects and methods}

With the assistance of the Work Inspection Service and the employers' association and a review of telephone books, 386 companies producing reinforced plastics in Denmark between 1964 and 1988 and 84 companies which had never produced reinforced plastics, but had produced other types of plastics or boats, were identified (8). All 50779 of the male workers employed in these 470 companies between 1964 and 1988 and alive on 1 January 1970 were identified by linkage of unique company identification numbers and personal identification numbers in a national pension fund. Altogether 36525 workers were employed in the companies with a verified production of reinforced plastics; 14254 workers were only employed in companies with no exposure to styrene.

In the national cancer register the nine patients with chronic myeloid leukemia (CML) and the 25 patients with acute myeloid leukemia (AML) diagnosed between 1970 and 1991 were identified in this population. A chromosome analysis of the bone marrow was searched for all 34 patients in the five cytogenetic laboratories operating in Denmark. For seven CML patients (78\%) and 12 AML patients (48\%) the results of an analysis carried out about the time of diagnosis were identified. None of the patients had a previous malignancy and the chromosome analyses were not secondary to chemotherapy. All the laboratories followed conventional methods and were not aware of the employment history of the patients when the analyses were conducted. Clonal chromosome aberrations were defined as present in at least two metaphases of the same supernumerary chromosome or the same structural aberration or if the same chromosome was missing in at least three metaphases. The leukemia diagnosis was confirmed for all the patients in a review of the medical records or pathology reports.

For each of the 19 leukemia patients with a chromosome analysis, three employees (referents) were sampled at random from the population at risk at the time the patients were diagnosed with leukemia (incidence density sampling). Matching by age ( \pm 1 year) was done, and a total of 57 referents were ascertained.

No direct measures of the employees' styrene exposure were available. Proxy measures were based on information on the extent of production of each company given by dealers of styrene and the company owners. All the employees were classified with a low or a high prob- ability of being directly exposed to styrene. Because a high proportion of the reinforced-plastics workers were employed in small companies with an average work force of less than 50 employees ( $77 \%$ of the workers with a probable high exposure) and because styrene is highly volatile, the employees could hardly completely avoid styrene exposure, however, even if they were not directly engaged in the production, especially in the early years of production (the 1960s), when styrene levels of workroom air of the production plants in Denmark were four times the present levels (7).

Unconditional and conditional logistic regression models were used to estimate the incidence rate ratio for myeloid leukemia with clonal chromosome aberrations. The probability of styrene exposure (three levels), year of first employment (two levels), and time since first employment (two levels) were included in the models in addition to age (five levels) and year of diagnosis (three levels), the latter two matching variables only in the unconditional models. All the odds ratios are presented with $95 \%$ confidence intervals.

\section{Results}

Out of six patients with chronic myeloid leukemia ever employed in the reinforced-plastics industry, five showed the 9;22 translocation, while the only unexposed patient had a normal karyotype (table 1). No other significant cytogenetic patterns were observed.

When all the myeloid leukemia cases with clonal chromosome aberrations were recognized as a common case group and were compared with all the incidence density sampled referents, a 2.5-fold increased risk was found for the reinforced-plastics workers (table 2). The risk was higher for the employees of the 1960s (the period of highest styrene exposure), and more than 10 years after being first exposed in employment. But the risk did not increase with the probability of styrene exposure and was confined to short-term workers. A conditional logistic regression analysis using only the matched sets showed similar results. When the seven patients with a normal karyotype were used as referents, higher risk estimates appeared for the reinforced-plastics workers (table 2).

A similar risk pattern was found if only AML cases with clonal chromosome aberrations were recognized as the case group, while no meaningful risk estimate was obtained for CML cases with clonal chromosome aberrations, as no case occurred among the nonstyrene-exposed workers.

\section{Discussion}

The increased risk of myeloid leukemia with clonal chromosome aberrations following exposure to styrene was estimated with low precision due to the small numbers, but the finding is to some extent supported by the in- 
Table 1. Karyotype of 19 male patients with myeloid leukemia working in the Danish reinforced plastics industry and similar industries with no styrene exposure. $(C M L=$ chronic myeloid leukemia, $A M L=$ acute myeloid leukemia)

\begin{tabular}{|c|c|c|c|c|c|}
\hline $\begin{array}{l}\text { Case } \\
\text { number }\end{array}$ & Leukemia & $\begin{array}{l}\text { Employed } \\
\text { in reinforced } \\
\text { plastics } \\
\text { industry }\end{array}$ & $\begin{array}{c}\text { Year of } \\
\text { diagnosis }\end{array}$ & $\begin{array}{l}\text { Age at } \\
\text { diagnosis } \\
\text { (years) }\end{array}$ & Karyotype \\
\hline 1 & CML & Yes & 1987 & 52 & $47, X Y, t(9 ; 22)(q 34 ; q 11)+10$ \\
\hline 2 & CML & Yes & 1983 & 33 & $46, X Y, t(9 ; 22)(q 34 ; q 11), \operatorname{del}(8)(q 24)$ \\
\hline 3 & CML & Yes & 1991 & 68 & $46, X Y, t(9 ; 22)(q 34 ; q 11)$, del $(17)(p ?)$ \\
\hline 4 & CML & Yes & 1982 & 45 & $46, X Y, t(9 ; 22)(q 34 ; q 11)$ \\
\hline 5 & CML & Yes & 1979 & 35 & $46, X Y, t(9: 22)(q 34: q 11)$ \\
\hline 6 & CML & Yes & 1979 & 72 & $46, X Y$ \\
\hline 7 & CML & No & 1980 & 23 & $46, X Y$ \\
\hline 8 & AML & Yes & 1987 & 67 & $46, X Y, t(17 ; 19)\left(q 12 ; q^{-12}\right)$ \\
\hline 9 & AML & Yes & 1984 & 41 & $46, X Y, \operatorname{dup}(1)(\mathrm{q} 21.2$ qter $), \operatorname{add}(14)(q ? 32)$ \\
\hline 10 & AML & Yes & 1986 & 59 & $47, X Y,+10$ \\
\hline 11 & AML & Yes & 1986 & 36 & $46, X Y$, del $(7)(q 3100)$, add $(8)(p ? 23)$, del(12)(p11.1p12.1) \\
\hline 12 & AML & Yes & 1988 & 64 & $46, X Y / 43, Y,-X,-2, \operatorname{der}(3) t(3 ; ?)(p 24 ; ?),-7,-7,-12,-16,-17,+\operatorname{der}(17) t(17 ; ?)(\mathrm{p} 11 ; ?),+2 \mathrm{mar}$ \\
\hline 13 & AML & Yes & 1991 & 28 & $47, X Y, \operatorname{del}(7)(\mathrm{p} 11.2 \mathrm{p} 14),+8$ \\
\hline 14 & AML & Yes & 1982 & 33 & $46, X Y$ \\
\hline 15 & AML & Yes & 1988 & 62 & $46, X Y$ \\
\hline 16 & AML & Yes & 1991 & 68 & $46, X Y$ \\
\hline 17 & $\mathrm{AML}$ & No & 1989 & 77 & $47, X Y,+8$, del(12p)(p11.1p12.1), del(17)(p?) \\
\hline 18 & AML & No & 1979 & 34 & $46, X Y$ \\
\hline 19 & AML & No & 1991 & 74 & $46, X Y$ \\
\hline
\end{tabular}

Table 2. Odds ratios for myeloid leukemia with clonal chromosome aberrations according to the probability of exposure to styrene, first year of employment, time since first employment, and length of employment in a company with styrene exposure. (OR $=$ odds ratio, $95 \% \mathrm{Cl}=95 \%$ confidence interval)

\begin{tabular}{|c|c|c|c|c|}
\hline $\begin{array}{l}\text { Employment } \\
\text { characteristics }\end{array}$ & $\begin{array}{l}\text { Cases } \\
(\mathrm{N})\end{array}$ & $\begin{array}{l}\text { Referents }{ }^{a} \\
\quad(N)\end{array}$ & $O R$ & $95 \% \mathrm{Cl}$ \\
\hline $\begin{array}{l}\text { Unexposed } \\
\text { employmentb }\end{array}$ & 1 & $\begin{array}{r}17 \\
3\end{array}$ & $\begin{array}{l}1.0 \\
1.0\end{array}$ & $\begin{array}{l}\text { (reference) } \\
\text { (reference) }\end{array}$ \\
\hline $\begin{array}{l}\text { Any exposed } \\
\text { employmentc }\end{array}$ & 11 & $\begin{array}{r}40 \\
4\end{array}$ & $\begin{array}{r}2.5 \\
10.3\end{array}$ & $\begin{array}{l}0.2-25.0 \\
0.7-156\end{array}$ \\
\hline \multicolumn{5}{|l|}{$\begin{array}{l}\text { Probability of } \\
\text { styrene exposure }\end{array}$} \\
\hline Low & 8 & $\begin{array}{r}24 \\
3\end{array}$ & $\begin{array}{l}3.0 \\
9.5\end{array}$ & $\begin{array}{l}0.3-32.2 \\
0.6-158\end{array}$ \\
\hline High & 3 & $\begin{array}{r}16 \\
1\end{array}$ & $\begin{array}{r}1.6 \\
12.6\end{array}$ & $\begin{array}{l}0.1-22.0 \\
0.5-348\end{array}$ \\
\hline \multicolumn{5}{|c|}{$\begin{array}{l}\text { Year of first } \\
\text { exposed employment }\end{array}$} \\
\hline Later than 1970 & 4 & $\begin{array}{r}21 \\
2\end{array}$ & $\begin{array}{l}2.3 \\
5.6\end{array}$ & $\begin{array}{l}0.2-26.2 \\
0.3-103\end{array}$ \\
\hline 1970 or before & 7 & $\begin{array}{r}19 \\
2\end{array}$ & $\begin{array}{r}5.9 \\
11.6\end{array}$ & $\begin{array}{l}0.6-57.8 \\
0.7-204\end{array}$ \\
\hline \multicolumn{5}{|c|}{$\begin{array}{l}\text { Time since first } \\
\text { exposed empioyment }{ }^{6}\end{array}$} \\
\hline$<10$ years & - & $\begin{array}{c}12 \\
1\end{array}$ & : & \\
\hline$\geq 10$ years & 11 & $\begin{array}{r}28 \\
3\end{array}$ & $\begin{array}{r}3.7 \\
17.1\end{array}$ & $\begin{array}{l}0.4-40.3 \\
0.9-332\end{array}$ \\
\hline \multicolumn{5}{|c|}{$\begin{array}{l}\text { Length of } \\
\text { exposed employment }\end{array}$} \\
\hline$<1$ year & 8 & $\begin{array}{r}20 \\
3\end{array}$ & $\begin{array}{r}5.9 \\
10.6\end{array}$ & $\begin{array}{l}0.5-74.3 \\
0.6-178\end{array}$ \\
\hline$\geq 1$ year & 3 & $\begin{array}{r}20 \\
1\end{array}$ & $\begin{array}{l}1.1 \\
9.7\end{array}$ & $\begin{array}{l}0.1-15.3 \\
0.3-29.4\end{array}$ \\
\hline \multicolumn{5}{|c|}{$\begin{array}{l}\text { a First line of referents represents the incidence density sampled within } \\
\text { the total study population. The second line represents myeloid leukemias } \\
\text { with a normal karyotype. } \\
\text { bmployment in a company with no styrene exposure. } \\
\text { Employment in a reinforced-plastics company with styrene exposure. } \\
\text { Employment in a reinforced-plastics company with a low or a high prob- } \\
\text { ability of being exposed to styrene. }\end{array}$} \\
\hline
\end{tabular}

creased incidence rate associated with employment during years of high levels of styrene exposure. The higher risk seen more than 10 years after first exposed employment is expected if an induction period and a latency interval is necessary for the leukemia causation. Increased risk was indicated for both acute and chronic myeloid leukemia with clonal chromosome aberrations. The two diseases have obvious differences, and separate analyses were preferable, but were hindered by the small numbers. The finding for acute myeloid leukemia is in agreement with previous reports on patients exposed to organic solvents (3). Little documentation exists concerning a possible association between chromosome aberrations in chronic myeloid leukemia and environmental exposures.

The 9;22 translocation (the Philadelphia chromosome) observed in five reinforced-plastics workers was the only specific chromosome aberration seen. The $7 \mathrm{q}$ - in case number 11 and the complex karyotype in case number 12 may also suggest exposure to genotoxic agents. As patients with secondary leukemia can show a variety of other karyotypes in bone marrow cells (9), the absence of chromosome aberrations specific for secondary leukemia does not argue, however, against exposures to leukemogenic agents in the other cases.

Chromosome analyses are not conducted on a routine basis in Denmark and were first introduced for nonscientific purposes during the late 1970s. Data were therefore ascertained for only $56 \%$ of all the myeloid leukemia patients. It is unlikely that exposure status played any role in the referral to cytogenetic examination. But the five cytogenetic laboratories cover separate geographic regions and different referral to cytogenetic examination at the laboratories associated with different frequencies 
of reinforced-plastics workers of the underlying catchment populations could have caused bias. For this reason comparisons were repeated with myeloid leukemia cases with a normal karyotype as the reference. The higher relative risks do not indicate bias due to a higher referral of patients from the reinforced-plastics industry for cytogenetic examination. These risk estimates have, however, to be interpreted with reservation because the reference category was not sampled at random from the study base and because of the small numbers.

The lack of information about possible confounding factors and the small number of observations limit the conclusions which can be drawn from this study, even if the study was conducted within a socioeconomically homogeneous population of industrial workers expected to have comparable (known and unknown) possible risk factors for leukemia. The higher risk for short-term workers indicates that life-style factors or exposures in industries other than the reinforced-plastics industry play a role. On the other hand, selection bias and information bias do not appear to have posed any validity problems.

The study suggests the presence of a clastogenic exposure among myeloid leukemia patients of the reinforced-plastics industry and styrene may be the culprit. The findings are, however, also in agreement with an increased risk for a subgroup of myeloid leukemia having chromosome aberrations as a part of the disease process. Due to the few observations, the lack of specific exposure data, and the incomplete case ascertainment, the results are only preliminary and suggestive. Additional studies are needed to corroborate or refute the present suggestive findings.

\section{Acknowledgments}

The study was supported by the Health Fund, Aarhus University Research Foundation, the Danish Research Academy, the Danish Working Environment Fund, and the Danish Cancer Society. We are grateful for the excel- lent cooperation with the Composite Section of the Danish Plastics Industry Association, without which this study could not have been completed.

\section{References}

1. Sandler DP, Collman GW. Cytogenetic and environmental factors in the etiology of the acute leukemias in adults. Am J Epidemiol 1987;126:1017-32.

2. Pedersen-Bjergaard J, Philip P, Larsen SO, Jensen G, Byrsting K. Chromosome aberrations and prognostic factors in therapy-related myelodysplasia and acute non-lymphocytic leakaemia. Blood 1990;76:1083-91.

3. Rodella $\mathrm{S}$, Ciccone $\mathrm{G}$, Rege-Cambrin G, Vineis $\mathrm{P}$, Working group on the epidemiology of hematolymphopoietic malignancies in Italy: cytogenetics and occupational exposures in acute nonlymphocytic leukemia and myelodysplastic syndrome. Scand J Work Environ Health 1993;19:369 _ 74.

4. International Agency for Research on Cancer (IARC). Some industrial chemicals. Lyon: IARC, 1994:233-320. IARC monographs on the evaluation of carcinogenic risks to humans, vol 60.

5. Meinhardt TJ, Lemen RA, Crandall MS, Young RJ. Environmental epidemiologic investigation of the styrene-butadiene rubber industry: mortality patterns with discussion of the hematopoietic and lymphatic malignancies. Scand J Work Environ Health 1982;8:250-59.

6. Kogevinas M, Ferro G, Andersen A, Bellander T, Biocca M, Coggon D, et al. Cancer mortality in a historical cohort study of workers exposed to styrene. Scand J Work Environ Health 1994;20:251-61.

7. Jensen AA, Breum NO, Bacher J, Lynge E. Occupational exposures to styrene in Denmark 1955-88. Am J Ind Med 1990;17: $593-606$.

8. Kolstad HA, Lynge E, Olsen J, Breum N. Incidence of lymphohematopoietic malignancies among styrene-exposed workers of the reinforced plastics industry. Scand J Work Environ Health $1994 ; 20: 272-8$.

9. Johansson B, Mertens F, Heim S, Kristofferson U, Mitelman F. Cytogenetics of secondary myelodysplasia (sMDS) and acute nonlymphocytic leukaemia (sANLL). Eur J Haematol 1991; $47: 17-27$.

Received for publication: 2 May 1995 